\title{
Study on CSR Performance of SME Tourism Enterprises
}

\author{
Xiao-Wen Jie ${ }^{1, a,{ }^{*}}$, Jin-Ye Huang ${ }^{2, b}$, Gui-Hua Dong ${ }^{3, c}$ \\ ${ }_{1,2,3}$ Sichuan University Chengdu China \\ ajiexw@vip.163.com, ${ }^{b} 18117866626 @ 163 . c o m,{ }^{c} 1981385805 @ q q . c o m$ \\ ${ }^{*}$ Corresponding author
}

Keywords: SME tourism enterprises, CSR countermeasures.

\begin{abstract}
This paper uses grounded theory in the foundation of collectingand collating a large number of domestic and foreign scholars about the research achievements on corporate social responsibility. Accordingtotheparticularity, complexity and stage characteristics of the development of small and medium-sized tourism enterprises environment,elaborating tourism enterprises problems with fulfilling their social responsibility, and putting forward some suggestions and countermeasures.
\end{abstract}

\section{Introduction}

With the rapid development of globalization and the deepening of reform, the tourism industry showed a bigger share of in the development of economy increase. At the same time, the rapid development of the tourism industry in China also led to problems of lacking responsibility in aspects of social, environmental, economic, cultural and other aspects of the community. These problems have caused the majority of scholars on the research and discussion of corporate social responsibility, to seek for a perfect and win-win solution.

At present, the social responsibility of the enterprise is not defined clearly, Public opinions are divergent. Bowen thought that the merchant's social responsibility was in accordance with social goals and values to make corresponding decisions and take concrete actions for the obligations of the ideal goal. However, in the pursuit of maximum profit era, Nobel laureate Friedman believes that corporate social responsibility means "according to the owners or shareholders of expect, to manage the affairs of the company, to comply with the basic rules of the society, to pursuit as much profit as possible under the legal and moral norms". Carol (1979) thought that corporate social responsibility refers to economics, legal, ethics, and charitable expectations at specific period of social organization, including economic responsibility, legal responsibility, ethical responsibility and charitable responsibility. Elkington (1997 ) proposed "three bottom line" concept in corporate social responsibility that enterprise management should contain three bottom line of social, economic and environmental line, economic responsibility is the traditional corporate responsibility, and environmental responsibility is the focus on the protection of the environment. At present, the research about tourism social responsibility has failed to attract enough attention, not only in academic circles, but also in the business community. But with the rapid development of the tourism industry, study and solving these problems want academic to give a preliminary theoretical framework to support and guidance. As for this, the author intends to put forward own suggestions and countermeasures about how to fulfill their social responsibility for tourism enterprises.

\section{The Analysis of SME Tourism Enterprises Social Responsibility}

\section{SME Tourism Enterprises Social Responsibility Content Dimension}

From the previous academic research point of view, we take more general attention to corporate social responsibility in the whole society, without considering the complexity and particularity of stakeholders in the tourism industry. At Here, according to tourism enterprises fulfilling their social responsibility problems, it introduces the cultural responsibility into the small and medium-sized 
tourism enterprises social responsibility system. Cultural responsibility refers to tourism enterprises, taking into account the protection of the tourism destination, folk customs, folk songs and other cultural treasures while providing tourism products and services. Therefore, Based on the research of corporate social responsibility, this paper puts forward the small and medium-sized tourism enterprises social responsibility for the content of seven dimension analysis theory, and divided into active and selective social responsibility social responsibility.

Tab.1 tourism enterprises social responsibility dimension of content analysis

\begin{tabular}{|c|c|c|}
\hline $\begin{array}{l}\text { Responsibility } \\
\text { category }\end{array}$ & $\begin{array}{l}\text { Dimension of } \\
\text { responsibility }\end{array}$ & The main content in detail \\
\hline \multirow[t]{2}{*}{$\begin{array}{l}\text { Active } \\
\text { social } \\
\text { responsibility }\end{array}$} & $\begin{array}{l}\text { Economic } \\
\text { responsibility }\end{array}$ & $\begin{array}{l}\text { 1. to provide maximum profits for small and medium- } \\
\text { sized tourismenterprises or corporate investors } \\
\text { 2. provide high efficiency and high quality tourism products and } \\
\text { services } \\
\text { 3. to maintain fair competition between rival and small and } \\
\text { medium-sized tourism enterprises }\end{array}$ \\
\hline & $\begin{array}{l}\text { Environmental } \\
\text { responsibility }\end{array}$ & $\begin{array}{l}\text { 1. to protect the natural ecological environment of tourism } \\
\text { destination and reduce the damage caused by } \\
\text { the excessive development } \\
\text { 2. toregulate and control the damage of tourists uncivilized } \\
\text { behavior to the environment } \\
\text { 3. in strict accordance with the number of reasonable arrangements } \\
\text { for visitors and } \\
\text { capacity saturation scenic environment }\end{array}$ \\
\hline \multirow[t]{5}{*}{$\begin{array}{l}\text { Selective } \\
\text { social } \\
\text { responsibility }\end{array}$} & $\begin{array}{l}\text { Community } \\
\text { Responsibility }\end{array}$ & $\begin{array}{l}\text { 1. to provide products and services and do not interfere tourist } \\
\text { destination of the normal life of nearby residents } \\
2 \text { regularly organize staff to provide free community } \\
\text { services, infrastructure construction and the donor community }\end{array}$ \\
\hline & $\begin{array}{l}\text { Legal } \\
\text { responsibility }\end{array}$ & $\begin{array}{l}\text { 1.to prohibit false travel products and services to visitors, or to } \\
\text { guide the visitors of unnecessary spending } \\
\text { 2.compliance with corporate tax obligations } \\
\text { 3.the prohibition of scenic environment destruction, to ensure the } \\
\text { safety of tourists }\end{array}$ \\
\hline & $\begin{array}{l}\text { Cultural } \\
\text { responsibility }\end{array}$ & $\begin{array}{l}\text { 1. to respect and protect tourist destinations, ethnic customs } \\
\text { and habits of ethnic minority culture } \\
\text { 2. to reduce the visitors to the scenic landscape destruction and raise } \\
\text { awareness of the protection of tourists } \\
\text { 3. regular organization of tourism destination residents of } \\
\text { the national cultural performance, to make the cultural } \\
\text { heritage and foreign tourists understood }\end{array}$ \\
\hline & $\begin{array}{l}\text { Employee } \\
\text { responsibility }\end{array}$ & $\begin{array}{l}\text { 1. to provide high quality products and services with } \\
\text { tourism tourists, to reduce rate complaints of visitors } \\
\text { 2. the tourists were satisfied with the handling of complaints } 100 \% \\
\text { 3. to provide high quality benefits for employees and regular } \\
\text { staff training, to improve the service consciousness of Science }\end{array}$ \\
\hline & $\begin{array}{l}\text { Charitable } \\
\text { responsibility }\end{array}$ & $\begin{array}{l}\text { 1. regularly join the hope project and the difficult crowd of donation } \\
\text { 2. be free for people who need help to provide travel products and } \\
\text { services }\end{array}$ \\
\hline
\end{tabular}

\section{The Willingness of Tourism Enterprises to Fulfill Their Social Responsibility}

In the performance of different degree of social responsibility, the subjective intention of tourism enterprises is not the same. On the basis of Carol's Pyramid model, seven different dimensions of social responsibility for the content of simple arrangement in low Pyramid is economic responsibility, which the majority of tourism enterprises are most willing to do, but charitable responsibility at the top of the Pyramid is not willing to perform their best. Because of tourism 
enterprises fulfilling their social responsibility, it need to consider the economic costs of various generated and the economic cost of size comparison.

\section{The Main Problems in the SME Tourism Enterprises to Fulfill Social Responsibility}

\section{Lack of Integrity Generates Low Quality of Products and Services.}

Integrity is the foundation and the magic key of the success of each enterprise. From the aspect of game theory, the result of lack of enterprise credit neither realizes the "win-win" positive-sum game nor the "rat race" zero -sum game but the "lose- lose" negative -sum game. At present, owing to lack of tourism enterprise credit trigger a series of problems. Such as, services that tourists enjoyed are totally different compared with those advertised by company; tourist guide lowers the standard of service; tourist guide disguises tourists to unnecessary spending; without tourist's permission, tourist agency only cuts tour program to save cost and etc. Such problems are so common that has a bad effect on tourism enterprises in the aspect of increasing sales revenue, promoting band image and forming customer loyalty. Especially for the influence of small and medium-sized enterprises is irreparable, even deadly.

\section{Excessive Tourism Development Produces Environmental Pollution and Destruction.}

In recent years, china's tourism industry has ushered in a little fast development period, which is closely related to big economy environment. However, it also triggers a thorny problem which makes the government, social public and even researchers fell overwhelmed. That is the environmental pollution and destruction caused by excessive tourism development and blind pursuit of economic benefits. Some typical cases are for example, during the "national day-golden week", some tourists are stranded on account of Jiuzhaigou scenic peaks, a lot of rubbish float on the Xihu, because of tourists' courteous behaviors, and dianchi lake blue-green algae event in Yunnan province.

\section{The Impact of Foreign Culture Leads to the Recession of Local and Native Culture.}

With the development of tourism industry, more and more ethnic minority areas get tourism commercialization development which unavoidably produces a series of culture collision problems. Local government, residents and enterprises of tourist destination use the uniqueness of local culture to attract a large number of foreign tourists to travel. Their major purposes are increasing the financial revenue for the government, raising the level of local employment, and improving the local people's life. However, with the entrance of foreign tourists who have different values and different cultural background, they not only bring positive aspects such as the augmentation of local revenue and economic development, but also they probably make local culture assimilation and dissimilation even the danger of vulgarization and distortion.

\section{Suggestions and Countermeasures}

As to the major problems on small and medium-sized enterprises shouldering social responsibilities, the author thinks, seeking solutions from the aspect of self-discipline, heteronomy and government's control.

\section{Optimizing Small and Medium-sized Enterprises' Mission and Enriching Their Values}

American scholar William James once said: "man's thought is because of all things you sow a kind of idea, reap an action; you sow an action, reap a habit; you sow a habit, reap a character; you sow a character, reap a destiny .In a word, all started with your concept." This is also suitable for small and medium-sized enterprises. Forming what kind of values give a significant impact on small and medium-sized enterprises' behaviors and results. Providing high quality service and tourism products to achieve social and environmental sustainable development or chasing financial value and enterprise profits maximization at the expense of benefits of environment, employers and 
tourists, it's a key decision for small and medium-sized enterprises. The formation of enterprise's historical mission and values plays a strategic guiding role and is the indicator of enterprise. What kind of historical mission of small and medium-sized enterprise decides what kind of value connotation it has, and what kind of value connotation decides what ways and methods to perform enterprises' social responsibilities.

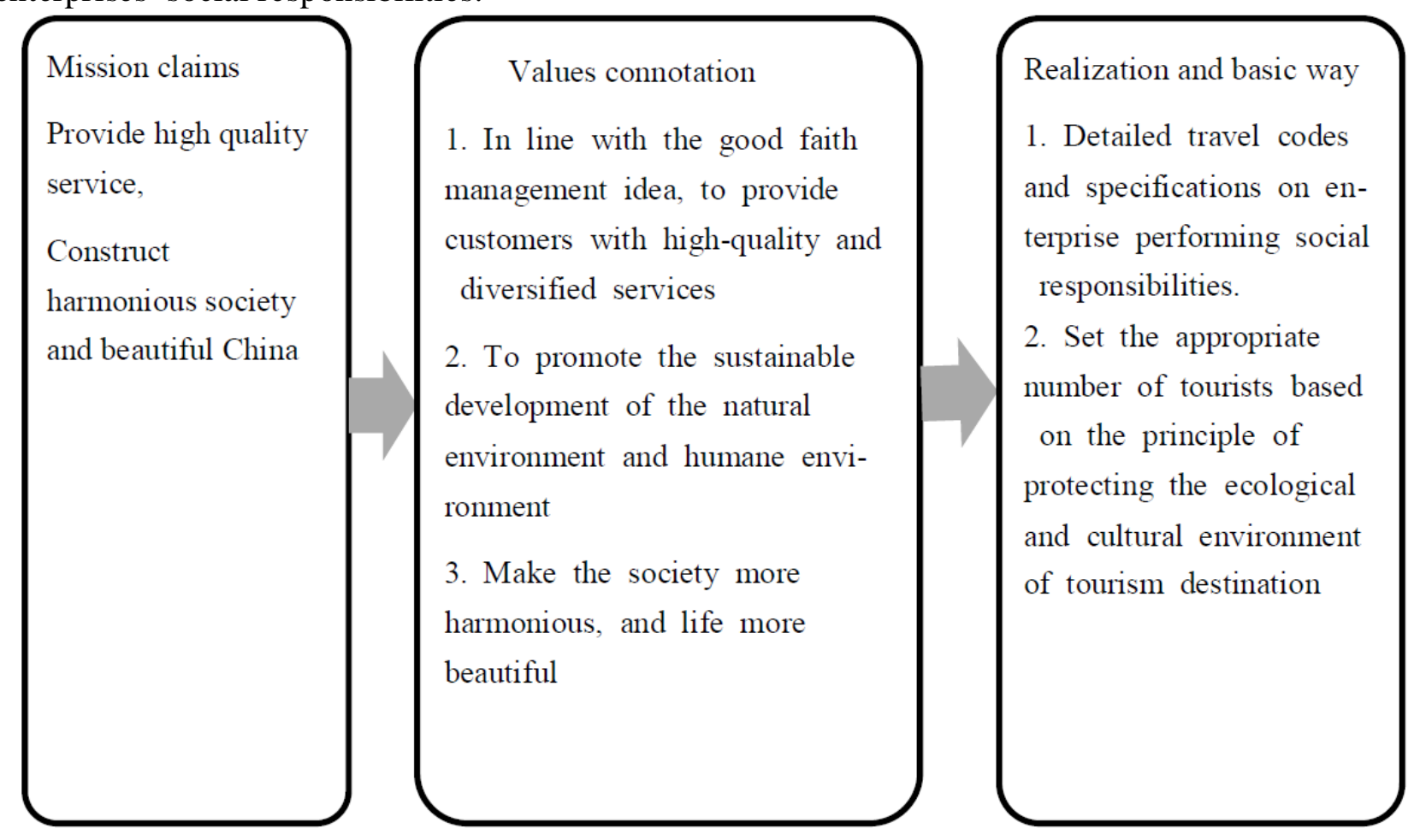

Fig. 2 The flow chart of small and medium-sized tourism enterprises mission and values

\section{Developing and Implementing Sustainable development Strategy and Pursuing Persistent and Sustainable Development}

Strategy points out the direction for enterprises' future development, directing enterprises how and by what ways to realize their mission and perform their social responsibilities. For what kind of sustainable development strategy enterprises will develop has aroused a heated discussion among government, social public, community residents, responsible person of tourism enterprises and academic researchers. The author thinks that the sustainable development strategy for small and medium-sized enterprises should be fully considered on the basic of bearing and saturation of natural and humane environment, be properly handle the relationship between economic interests and interests of whole society, between foreign culture and native culture, give consideration to long-term development appeal of environment and culture and to interest conflict among each stakeholder.

\section{Introducing a Third Party Credit Rating System to Play the Role of Public Supervision}

Undoubtedly, the development of the Internet is a big step in modern society, following with more and more direct or indirect contacts between enterprises and the Internet, which is same for the small and medium-sized tourism enterprises The success of Taobao B2C shopping mode and customer evaluation system greatly inspired the small and medium-sized tourism enterprises with social responsibility to build a third party rating system. Among them, the source of data for the third party credit rating agency comes from following three categories: the evaluation of tourists, the evaluation of tourist destination residents and the evaluation of the public and the media. This would play a certain guiding role when they choose products and services.As for the small and medium-sized tourism enterprises, their existed problems would be promptly corrected after they 
mastered the customers' reaction for their service of products and their performance of the social responsibility.

\section{References}

[1] Bowen, H.Social Responsibility of the Businessman[M]. New York: Harper\&Row,1953.31.

[2] Freeman, R E, Reed D L. Stockholders and stakeholders: a new perspective on corporate governance[J]. CaliforniaManagement Review,1983.

[3] Elkington J. Cannibals with Forks: The Triple Bottom Line of 21st Century Business [M]. Oxford: Capstone Publishing Ltd, 1997.30-52.

[4] Carroll.A.B.1979A three dimensional conceptual model of corporate social performance, in Academy of Management Review(4), pp.497-505.

[5] Eells. R and Walton, 1961, Conceptual Foundation of Business, Homewood, ill: Richard D.Irw in.

[6]Carroll, A. B. (1991). The pyramid of Corporate Social Responsibility:Toward the moral management of organizational stakeholders. Business Horizons, 34(4), 39-48.

[7] Carroll, A. B. (1999). Corporate Social Responsibility: Evolution of adefinitional construct. Business and Society, 38, 268-295.

[8] Carroll, A. B., \&Shabana, K. M. (2010). The business case forCorporate Social Responsibility: A review of concepts, researchand practice. International Journal of Management Reviews,12(1), 85-105.

[9] Aguinis, H., \&Glavas, A. (2012). What we know and don't knowaboutCorporate Social Responsibility: A review and researchagenda. Journal of Management, 18(4), 932-968. 